\title{
Nigeria and Italy Divergences in Coronavirus Experience: Impact of Population Density
}

\author{
Emmanuel O. Amoo ${ }^{1 D},{ }^{1}$ Olujide Adekeye, ${ }^{2}$ Adebanke Olawole-Isaac, ${ }^{1}$ Fagbeminiyi Fasina, ${ }^{1}$ \\ Paul O. Adekola $\mathbb{D}^{1},{ }^{1}$ Gbemisola W. Samuel, ${ }^{1}$ Moses A. Akanbi, ${ }^{1}$ Muyiwa Oladosun, ${ }^{1}$ \\ and Dominic E. Azuh ${ }^{1}$
}

${ }^{1}$ Demography and Social Statistics, College of Business and Social Sciences, Covenant University, Ota, Ogun State, Nigeria

${ }^{2}$ Department of Psychology, College of Leadership Development Studies, Covenant University, Ota, Ogun State, Nigeria

Correspondence should be addressed to Emmanuel O. Amoo; emma.amoo@covenantuniversity.edu.ng

Received 10 April 2020; Accepted 1 May 2020; Published 1 June 2020

Academic Editor: Daiji Endoh

Copyright (c) 2020 Emmanuel O. Amoo et al. This is an open access article distributed under the Creative Commons Attribution License, which permits unrestricted use, distribution, and reproduction in any medium, provided the original work is properly cited.

\begin{abstract}
Background. The reports and information on coronavirus are not conspicuously emphasising the possible impact of population density on the explanation of difference in rapid spread and fatality due to the disease and not much has been done on bicountry comparisons. Objective. The study examined the impact of population density on the spread of COVID-19 pandemic in two sociodemographic divergent countries. Methods. The study conducted a scoping review of published and unpublished articles including blogs on incidences and fatalities of COVID-19. The analysis followed qualitative description and quantitative presentation of the findings using only frequency distribution, percentages, and graphs. Results. The two countries shared similar experience of "importation" of COVID-19, but while different states ordered partial lockdown in Nigeria, it was an immediate total lockdown in Italy. The physician/patient ratio is high in Italy $(1: 328)$ but low in Nigeria $(1: 2500)$, while population density is 221 in Nigeria and 206 in Italy. Daily change in incidence rate reduced to below 20\% after 51 and 30 days of COVID-19 first incidence in Italy and Nigeria, respectively. Fatality rate has plummeted to below $10 \%$ after the $66^{\text {th }}$ day in Italy but has not been stabilised in Nigeria. Conclusion. The authors upheld both governments' recommending measures that tilted towards personal hand-hygienic practices and social distancing. Authors suggested that if Italy with its high physician/patient ratio and lower population density compared to Nigeria could suffer high fatality from COVID-19 pandemic under four weeks, then Nigeria with its low physician/patient ratio and higher population density should prepare to face harder time if the pandemic persists.
\end{abstract}

\section{Introduction}

As Nigeria was grappling with the challenge of high level of insurgency besetting certain parts of her territory in early 2000s, the devastating blow from Ebola pandemic (2014) came in and almost grounded her economy but with the proactiveness of her healthcare system that quickly doused the tension which culminated in declaration of the country free of Ebola by October 2014 [1, 2]. Ebola virus ravaged more than 11000 lives in Nigeria's neighbouring countries mainly in Liberia, Sierra Leone, and Guinea $[3,4]$. It adversely affected communities and cities such as Conakry and Macenta (in Guinea); Kailahun, Kenema, Bombali, Port
Loko, Western Rural and Western Urban (in Sierra Leone); Montserrado in Liberia, to mention but few $[5,6]$, according to the Centers for Disease Control and Prevention [7, 8]. However, as the country is scouting for strategies to attain the goals of sustainable development and Agenda 2063, in the face of fighting against incessant and highly reported serial killings, the communal conflicts, and herdsmenfarmers clashes [9-12], Lassa fever crept in [13]. Currently, the country is engulfed in a big fight for protection of lives under the mystifying coronavirus (COVID-19) that just reared up its ugly head [14-16].

Italy also, has in the last few years been faced with turbulence of severe landslides, floods, and bridge collapse 
[17-19] and is currently facing the public health challenge of COVID-19 pandemic. Cumulative casualties due to landslides, floods, and other recurring environmental challenges in Italy from retrospective data analysis was reported to be 50,593 comprised of dead, missing, or injured persons $[20,21]$. As at March 31, 2020, Italy has recorded the highest death rate due to COVID-19 among other countries of the world. The public concern now is due to the alarming levels of spread and the fatality across the globe and the general question is how can this be quickly curtailed? The study analyzed whether sociodemographic divergency (such as population density) could have an impact on the spread of COVID-19.

Generally, the propensity for disease transmission is higher among the people that live in close proximity [22, 23]. Human population density is the number of people per unit of area, usually quoted per square kilometer (or square mile) which may include or exclude water areas or glaciers, denoted as population density $=$ total population/land area in square $\mathrm{km}$. Although the nature of the population density (which could be low or high) may not be a direct determinant of rapid spread of infections, there is high propensity for a densely populated area to become overcrowded, which could spur challenges in sanitation and declined quality of living conditions and potentially serves as breeding venue for infectious agents and rapid transmission [22-25]. When emergency cases therefore arise, the ease of curing the disease and the health system in addition to distribution of healthcare materials are often strained.

The name coronavirus is derivative of the Latin word "corona" that means "crown." Biologically, they are named coronaviruses because they have spiky projections on their surface that look like crowns [26, 27]. The virus that is responsible for coronavirus disease belongs to the genus Betacoronavirus that cause several respiratory illness and other symptoms such as pneumonia, fever, breathing difficulty, and lung infection. Severe acute respiratory syndrome coronavirus 2 (SARS-CoV-2) is the virus strain that causes coronavirus disease (called COVID-19) [28, 29]. It is colloquially called coronavirus, previously referred to as 2019 novel coronavirus (2019-nCoV). There are diverse types of coronaviruses, such as SARS-CoV (the severe acute respiratory syndrome that was first identified in 2003), MERS-CoV (the virus that caused Middle East respiratory syndrome, first discovered in 2012), and the new SARSCoV-2 that causes COVID-19 [26, 27, 30]. Specifically, COVID-19 was first identified in Wuhan City, Hubei Province, in China on December 29, 2019 [31-33]. World Health Organisation officially reported coronavirus on December 31, 2019, and by March 11 the disease was declared as a pandemic $[34,35]$, and it has since remained a public health emergency of international concern. Coronavirus incubation period is indicated to be 14 days, and median time from onset of the symptoms to intensive care unit admission is relatively 10 days, but the time between the onset and death is 2-8 weeks [27, 36-39].

Several factors have been suspected as the root cause of the spread of COVID-19, which include but not limited to lack of awareness, close contact with infected people, and touching eyes, nose, and mouth with contaminated hands [36-40]. Others include low hygiene behavioural practices and bilateral relationships between and among countries that permit cross-border travelling. Considering all these reports and information on coronavirus till date, there is no much emphasis on population density and major bicountry comparison on why the fatality is rapid and high in one country but low in another. This review is to provide additional information on the spread of the COVID-19 pandemic and increase the awareness on measures to curb the spread, and it also serves as an additional relevant resource to already existing literature on the infectious virus and its rapid spread.

\section{Coronavirus in Italy and Nigeria: The Connections}

The ties between Nigeria and Italy are rooted in decades of bilateral businesses where Italians establish business (companies) in Nigeria and Nigerians live and work in Italy, with each party paying dynamic attention to and respecting the rules, regulations, and sovereignty of each country. Nigeria has her embassy in Rome while Italy has the same and a consulate in Lagos. The two countries trade and exchange materials from leather to plastics and packaging, pharmaceuticals, building materials, training, intelligence sharing, and logistics supply, including technology and establishment of Italian Trade Agency (ITA) in Lagos State [41]. The relationship between the two countries has been peaceful and constructive, and there has not been any conspicuous trait that the tie may nose-dive or possibly collapse.

However, coronavirus in Nigeria could be linked to the international relationship between Italy and Nigeria that permitted cross-border travels between the two countries. The two countries had a similar first experience of coronavirus as an "imported disease" because it did not originate from either of the countries. As the pandemic sneaked into Nigeria through an Italian national, it also entered Italy via two tourists from China. Specifically, the two Chinese tourists (in Italy) were tested positive in Rome on January 31, 2020 [42, 43]. The third confirmed case in Italy was a repatriated Italian from the city of Wuhan (China) barely a week after the first two index cases were identified $[28,43]$. The disease then started invading the nooks and crannies of Italy starting from a cluster of 16 cases in Lombardy, which later increased to 60 , to the record of the first COVID-19 death in February 22, 2020 [28, 43]. Since then, the case-fatality rate has been very high and currently (as at March 31, 2020) accounting for almost one-third of the global deaths.

Weeks after the disease has been taking its toll on Italy, the disease started in Nigeria. The first reported index case of coronavirus disease in Nigeria was an Italian citizen in Lagos who tested positive to SARS-CoV-2 on February 27, 2020. The second case was reported on March 9, being the Nigerian contact of the first index case at the destination the infected Italian visited. The first Nigerian case was also the first case of the coronavirus in sub-Saharan Africa. 
Thereafter, other countries in the region have since recorded confirmed cases of COVID- 19.

Nigeria is the largest and most densely populated country in Africa and the $7^{\text {th }}$ largest population in the world, with approximately 200 million people on a land mass area of $920,000 \mathrm{~km}(360,000 \mathrm{sq} \mathrm{mi})$. Approximately more than $60 \%$ of Nigerians are urban dwellers, and the urbanization rate is estimated at $4.3 \%$. Over $60 \%$ are younger than 25 years and the aged population is only $3.3 \%$ (Central Intelligence Agency) [44]. Italy, on the other hand, is a country of over 60 million people, and has 20 regions (regioni) divided into 110 provinces $[45,46]$. It is one of the countries in Europe with a higher proportion of the aged. In Asia and Europe, the two continents that are home to the world's oldest populations ( $\geq 65$ years), Japan shares $28 \%$ of the world aged population; Monaco, 26\%; Italy, 23\%; China, 12\%; United States, $16 \%$. However, India (in Asia) and Nigeria (in Africa) share only $6 \%$ and $3 \%$, respectively (Population Reference Bureau) [47].

\section{Materials and Methods}

The study adopted a scoping review of published and unpublished articles including blogs covering updates on coronavirus incidences, deaths, and other related pandemichealth reports. For the data, population figures, density, and land area were extracted from 2019 world population data sheet, while data for coronavirus including the fatality and incidence cases, physician/persons, and so on were obtained using World Health Organisation Reports, NationMaster, World Bank Group, and worldometer. Certain information on daily occurrence of coronavirus in Italy and Nigeria was obtained from Dipartimento della Protezione Civile and Nigeria Center for Disease Control (NCDC). While the NCDC is Nigeria's national public health institute mandated to lead the preparedness, detection, and response to infectious disease outbreaks and public health emergencies, the Dipartimento della Protezione Civile is the only national body in Italy that is saddled with the responsibility of predicting, preventing, and managing emergency events such as national level disasters or catastrophes, both natural and human-made. The World Population Data Sheet, published by the Population Research Bureau (PRB), provides information on the key population, health, and environment indicators for more than 200 countries, and it is published annually. In terms of physician per 1000 person, the statistics available for Europe and Central Asia were used for the continent, respectively, while data for sub-Saharan Africa was imitated for Africa as a whole $[48,49]$.

We followed qualitative and quantitative descriptive analysis of the findings, reiterated the obvious consequences, and highlighted our assumed implications towards immediate solution to the spread of the epidemic and its further consequences. For the choice of the countries of study, we selected two countries with demographic variants. Life expectancy in the two countries are not the same. While Italy is the $5^{\text {th }}$ country in the world with highest life expectancy, 83.4 years (male $=81.1$; female $=85.4$ ) [50], Nigeria is one of the countries with lowest life expectancy rate with an average of
55.2 years (male, 54.7; female, 55.7) [51, 52]. The larger proportion of Nigerian population is young people $(\leq 15$ years), and the average age of the Italian population is 45.2 years and aged represent $21.7 \%$ of the Italian population [44].

\section{Results}

There are several reports on the incidences and fatality consequences of coronavirus. While only few are published, there is a lot of information on the coronavirus pandemic, which cannot be discarded in an emergency period like this. In an emergency period, every information should count. We reviewed several of these categories, sieved the reports where necessary, made a number of comparisons among different information, and extracted them for analysis. Although the information reviewed revealed that the topmost (as at 31 March 2020) in terms of COVID-19 incidence in Africa were South Africa (1326) and Egypt (609), Asia, China, Iran, and Turkey have recorded above 10,000 cases (China, 82241; Iran, 41495; Turkey, 11535) [53]. By April 26, 2020, Italy cases have gone up to 197,675 (Table 1), while Nigeria reported 1,273 cases (Table 1). However, the death tolls are highest in Italy $(26,664)$ compared to other countries of the world and especially when compared with the death toll of 40 persons reported for Nigeria (Table 1).

The computations of percentage change in the incidences and fatalities rates from the compiled COVID-19 data for Italy and Nigeria are presented also in Table 1. The data were extracted mainly from Dipartimento della Protezione Civile (for Italy) and Nigeria Centre for Disease Control (NCDC) (for Nigeria), among others. The data covered only the time between the record of the first index case in the two countries and April 26, 2020. While the prevalence of COVID-19 has spanned 96 days in Italy, it has existed in Nigeria for 60 days at the time of this report.

Specifically, the incidences and fatalities from COVID19 as at April 26, 2020 show that the incidence was staggering (at least) in the first three weeks in Nigeria. In Italy, the record was alarmingly galloping, crossed a thousand within the first six weeks of the incidence and increased to 10149 cases at exactly the $7^{\text {th }}$ week (March 10,2020$)$ from the first incidence at January 31, 2019 (Table 1). While COVID19 was 12 days old in Nigeria before the country recorded the first death on March 9, 2020, there was no record of death in Italy until the $31^{\text {st }}$ day of COVID-19 in the country. However, at the time Nigeria was recording the first causality, Italy has recorded relatively half a thousand deaths (specifically, 463 persons). The result also revealed that the highest fatality percentage change $(66.7-100.0 \%)$ was recorded for Italy around the $4^{\text {th }}$ week from the first index case (Table 1). In addition, the analysis revealed that Nigeria experienced the highest level of fatality $(133.0 \%)$ at the $4^{\text {th }}$ week of incidence compared to Italy's experience around the same $4^{\text {th }}$ week from the first index case.

The declining rate for the incidence in Nigeria was remarkable in the first two weeks of April $(\leq 10 \%$ on the average). We observed similar trends from Italy data where the incidence percentage change plummeted and remained 
TABLe 1: Incidences and fatalities from COVID-19 in Italy and Nigeria as at April 26, 2020.

\begin{tabular}{|c|c|c|c|c|c|c|c|c|c|c|}
\hline & & & Italy & & & & & Nigeria & & \\
\hline & $\begin{array}{c}\text { Date } \\
\text { from } 1^{\text {st }} \\
\text { incidence }\end{array}$ & $\begin{array}{c}\text { Cumulative } \\
\text { cases }\end{array}$ & $\begin{array}{c}\text { Cumulative } \\
\text { deaths }\end{array}$ & $\begin{array}{l}\text { Incidence } \\
\% \text { change }\end{array}$ & $\begin{array}{c}\text { Fatality } \\
\% \\
\text { change }\end{array}$ & $\begin{array}{c}\text { Date } \\
\text { from } 1^{\text {st }} \\
\text { incidence }\end{array}$ & $\begin{array}{c}\text { Cumulative } \\
\text { cases }\end{array}$ & $\begin{array}{c}\text { Cumulative } \\
\text { deaths }\end{array}$ & $\begin{array}{l}\text { Incidence } \\
\% \text { change }\end{array}$ & $\begin{array}{c}\text { Fatality } \\
\% \\
\text { change }\end{array}$ \\
\hline $1 / 31 / 2020$ & $1 \mathrm{st}$ & 2 & 0 & - & - & & & & & \\
\hline $2 / 21 / 2020$ & 31 st & 20 & 1 & - & - & & & & & \\
\hline $2 / 22 / 2020$ & $32 \mathrm{nd}$ & 79 & 2 & 295.0 & 100.0 & & & & & \\
\hline $2 / 23 / 2020$ & $33 \mathrm{rd}$ & 150 & 3 & 89.9 & 50.0 & & & & & \\
\hline $2 / 24 / 2020$ & 34 th & 229 & 6 & 52.7 & 100.0 & & & & & \\
\hline $2 / 25 / 2020$ & 35 th & 322 & 10 & 40.6 & 66.7 & & & & & \\
\hline $2 / 26 / 2020$ & 36th & 445 & 12 & 38.2 & 20.0 & & & & & \\
\hline $2 / 27 / 2020$ & 37 th & 650 & 17 & 46.1 & 41.7 & 1st & 1 & - & - & - \\
\hline $2 / 28 / 2020$ & 38th & 888 & 21 & 36.6 & 23.5 & 2nd & - & - & - & - \\
\hline $2 / 29 / 2020$ & 39th & 1,128 & 29 & 27.0 & 38.1 & $3 \mathrm{rd}$ & - & - & - & - \\
\hline $3 / 1 / 2020$ & 40th & 1,694 & 34 & 50.2 & 17.2 & 4 th & - & - & - & - \\
\hline $3 / 2 / 2020$ & $41 \mathrm{st}$ & 2,036 & 52 & 20.2 & 52.9 & 5 th & - & - & - & - \\
\hline $3 / 3 / 2020$ & $42 \mathrm{nd}$ & 2,502 & 79 & 22.9 & 51.9 & 6th & - & - & - & - \\
\hline $3 / 4 / 2020$ & 43rd & 3,089 & 107 & 23.5 & 35.4 & 7th & - & - & - & - \\
\hline $3 / 5 / 2020$ & 44th & 3,858 & 148 & 24.9 & 38.3 & 8 th & - & - & - & - \\
\hline $3 / 6 / 2020$ & 45th & 4,636 & 197 & 20.2 & 33.1 & 9th & - & - & - & - \\
\hline $3 / 7 / 2020$ & 46th & 5,883 & 233 & 26.9 & 18.3 & 10th & - & - & - & - \\
\hline $3 / 8 / 2020$ & 47 th & 7,375 & 366 & 25.4 & 57.1 & 11 th & - & - & - & - \\
\hline $3 / 9 / 2020$ & 48th & 9,172 & 463 & 24.4 & 26.5 & 12 th & 2 & 1 & 100 & 0 \\
\hline $3 / 10 / 2020$ & 49th & 10,149 & 631 & 10.7 & 36.3 & 13th & - & - & - & - \\
\hline $3 / 11 / 2020$ & 50 th & 12,462 & 827 & 22.8 & 31.1 & 14 th & - & - & - & - \\
\hline $3 / 12 / 2020$ & 51st & 15,113 & 1,016 & 21.3 & 22.9 & 15 th & - & - & - & - \\
\hline $3 / 13 / 2020$ & 52nd & 17,660 & 1,266 & 16.9 & 24.6 & 16th & 1 & 1 & -50 & 0 \\
\hline $3 / 14 / 2020$ & $53 \mathrm{rd}$ & 21,157 & 1,441 & 19.8 & 13.8 & 17 th & - & - & - & - \\
\hline $3 / 15 / 2020$ & 54 th & 24,747 & 1,809 & 17.0 & 25.5 & 18th & - & - & - & - \\
\hline $3 / 16 / 2020$ & 55th & 27,980 & 2,158 & 13.1 & 19.3 & 19th & - & - & - & - \\
\hline $3 / 17 / 2020$ & 56th & 31,506 & 2,503 & 12.6 & 16.0 & 20th & 2 & 1 & 100.0 & 0.0 \\
\hline $3 / 18 / 2020$ & 57 th & 35,713 & 2,978 & 13.4 & 19.0 & $21 s t$ & 7 & 1 & 250.0 & 0.0 \\
\hline $3 / 19 / 2020$ & 58th & 41,035 & 3,405 & 14.9 & 14.3 & $22 \mathrm{nd}$ & 11 & 1 & 57.1 & 0.0 \\
\hline $3 / 20 / 2020$ & 59th & 47,021 & 4,032 & 14.6 & 18.4 & $23 \mathrm{rd}$ & 12 & 1 & 9.1 & 0.0 \\
\hline $3 / 21 / 2020$ & 60th & 53,578 & 4,825 & 13.9 & 19.7 & 24 th & 22 & 1 & 83.3 & 0.0 \\
\hline $3 / 22 / 2020$ & $61 \mathrm{st}$ & 59,138 & 5,475 & 10.4 & 13.5 & 25 th & 30 & 2 & 36.4 & 100.0 \\
\hline $3 / 23 / 2020$ & $62 \mathrm{nd}$ & 63,927 & 6,077 & 8.1 & 11.0 & 26th & 36 & 2 & 20.0 & 0.0 \\
\hline $3 / 24 / 2020$ & $63 \mathrm{rd}$ & 69,176 & 6,820 & 8.2 & 12.2 & 27 th & 44 & 2 & 22.2 & 0.0 \\
\hline $3 / 25 / 2020$ & 64th & 74,386 & 7,503 & 7.5 & 10.0 & 28th & 51 & 2 & 15.9 & 0.0 \\
\hline $3 / 26 / 2020$ & 65th & 80,539 & 8,215 & 8.3 & 9.5 & 29th & 65 & 2 & 27.5 & 0.0 \\
\hline $3 / 27 / 2020$ & 66th & 86,498 & 9,134 & 7.4 & 11.2 & 30th & 81 & 3 & 24.6 & 50.0 \\
\hline $3 / 28 / 2020$ & 67 th & 92,472 & 10,023 & 6.9 & 9.7 & 31 st & 97 & 3 & 19.8 & 0.0 \\
\hline $3 / 29 / 2020$ & 68th & 97,389 & 10,779 & 5.3 & 7.5 & $32 \mathrm{nd}$ & 111 & 3 & 14.4 & 0.0 \\
\hline $3 / 30 / 2020$ & 69th & 101,739 & 11,591 & 4.5 & 7.5 & $33 \mathrm{rd}$ & 131 & 7 & 18.0 & 133.3 \\
\hline $3 / 31 / 2020$ & 70th & 105,792 & 12,428 & 4.0 & 7.2 & 34th & 151 & 7 & 15.3 & 0.0 \\
\hline $4 / 1 / 2020$ & 71 st & 110,574 & 13,155 & 4.5 & 5.8 & 35th & 174 & 7 & 15.2 & 0.0 \\
\hline $4 / 2 / 2020$ & $72 \mathrm{nd}$ & 115,242 & 13,915 & 4.2 & 5.8 & 36th & 184 & 7 & 5.7 & 0.0 \\
\hline $4 / 3 / 2020$ & 73rd & 119,827 & 14,681 & 4.0 & 5.5 & 37 th & 209 & 7 & 13.6 & 0.0 \\
\hline $4 / 4 / 2020$ & 74th & 124,632 & 15,362 & 4.0 & 4.6 & 38th & 214 & 7 & 2.4 & 0.0 \\
\hline $4 / 5 / 2020$ & 75th & 128,948 & 15,887 & 3.5 & 3.4 & 39th & 232 & 7 & 8.4 & 0.0 \\
\hline $4 / 6 / 2020$ & 76th & 132,547 & 16,523 & 2.8 & 4.0 & 40th & 238 & 7 & 2.6 & 0.0 \\
\hline $4 / 7 / 2020$ & 77 th & 135,586 & 17,127 & 2.3 & 3.7 & $41 s t$ & 254 & 7 & 6.7 & 0.0 \\
\hline $4 / 8 / 2020$ & 78th & 139,422 & 17,669 & 2.8 & 3.2 & $42 \mathrm{nd}$ & 274 & 7 & 7.9 & 0.0 \\
\hline $4 / 9 / 2020$ & 79th & 143,626 & 18,279 & 3.0 & 3.5 & $43 \mathrm{rd}$ & 288 & 7 & 5.1 & 0.0 \\
\hline $4 / 10 / 2020$ & 80th & 147,577 & 18,849 & 2.8 & 3.1 & 44th & 305 & 7 & 5.9 & 0.0 \\
\hline $4 / 11 / 2020$ & 81st & 152,271 & 19,468 & 3.2 & 3.3 & 45th & 318 & 10 & 4.3 & 42.9 \\
\hline $4 / 12 / 2020$ & 82nd & 156,363 & 19,899 & 2.7 & 2.2 & 46th & 323 & 10 & 1.6 & 0.0 \\
\hline $4 / 13 / 2020$ & $83 \mathrm{rd}$ & 159,516 & 20,465 & 2.0 & 2.8 & 47 th & 343 & 10 & 6.2 & 0.0 \\
\hline $4 / 14 / 2020$ & 84th & 162,488 & 21,067 & 1.9 & 2.9 & 48th & 373 & 11 & 8.7 & 10.0 \\
\hline $4 / 15 / 2020$ & 85th & 165,155 & 21,645 & 1.6 & 2.7 & 49th & 407 & 12 & 9.1 & 9.1 \\
\hline $4 / 16 / 2020$ & 86th & 168,941 & 22,170 & 2.3 & 2.4 & 50 th & 442 & 13 & 8.6 & 8.3 \\
\hline
\end{tabular}


TABLE 1: Continued.

\begin{tabular}{|c|c|c|c|c|c|c|c|c|c|c|}
\hline & \multicolumn{5}{|c|}{ Italy } & \multicolumn{5}{|c|}{ Nigeria } \\
\hline & $\begin{array}{c}\text { Date } \\
\text { from } 1^{\text {st }} \\
\text { incidence }\end{array}$ & $\begin{array}{c}\text { Cumulative } \\
\text { cases }\end{array}$ & $\begin{array}{c}\text { Cumulative } \\
\text { deaths }\end{array}$ & $\begin{array}{l}\text { Incidence } \\
\% \text { change }\end{array}$ & $\begin{array}{c}\text { Fatality } \\
\% \\
\text { change }\end{array}$ & $\begin{array}{c}\text { Date } \\
\text { from } 1^{\text {st }} \\
\text { incidence }\end{array}$ & $\begin{array}{c}\text { Cumulative } \\
\text { cases }\end{array}$ & $\begin{array}{c}\text { Cumulative } \\
\text { deaths }\end{array}$ & $\begin{array}{l}\text { Incidence } \\
\% \text { change }\end{array}$ & $\begin{array}{c}\text { Fatality } \\
\% \\
\text { change }\end{array}$ \\
\hline $4 / 17 / 2020$ & 87 th & 172,434 & 22,745 & 2.1 & 2.6 & $51 \mathrm{st}$ & 493 & 17 & 11.5 & 30.8 \\
\hline $4 / 18 / 2020$ & 88th & 175,925 & 23,227 & 2.0 & 2.1 & $52 \mathrm{nd}$ & 541 & 19 & 9.7 & 11.8 \\
\hline $4 / 19 / 2020$ & 89th & 178,972 & 23,660 & 1.7 & 1.9 & 53rd & 627 & 21 & 15.9 & 10.5 \\
\hline $4 / 20 / 2020$ & 90th & 181,228 & 24,114 & 1.3 & 1.9 & 54 th & 665 & 22 & 6.1 & 4.8 \\
\hline $4 / 21 / 2020$ & $91 \mathrm{st}$ & 183,957 & 24,648 & 1.5 & 2.2 & 55 th & 782 & 25 & 17.6 & 13.6 \\
\hline $4 / 22 / 2020$ & 92nd & 187,327 & 25,085 & 1.8 & 1.8 & 56 th & 873 & 28 & 11.6 & 12.0 \\
\hline $4 / 23 / 2020$ & 93rd & 189,973 & 25,549 & 1.4 & 1.8 & 57 th & 981 & 31 & 12.4 & 10.7 \\
\hline $4 / 24 / 2020$ & 94th & 192,994 & 25,969 & 1.6 & 1.6 & 58th & 1098 & 35 & 11.9 & 12.9 \\
\hline $4 / 25 / 2020$ & 95th & 195,351 & 26,384 & 1.2 & 1.6 & 59th & 1182 & 35 & 7.7 & 0.0 \\
\hline $4 / 26 / 2020$ & 96th & 197,675 & 26,644 & 1.2 & 1.0 & 60th & 1273 & 40 & 7.7 & 14.3 \\
\hline
\end{tabular}

Sources: The Protezione Civile (2020); Nigeria Centre for Disease Control (NCDC) (2020); and other unpublished works.

below 5.0\% in April. Both countries relatively experienced lower reduction in the incidence rates in April. The computation from the Nigeria data really shows that the incidence percentage change has not exceeded $15-20 \%$ for long range of weeks (precisely, throughout April).

Granted that the dates of occurrence of COVID-19 in the two countries were not the same at the initial stage, records for concurrent data started on March 17, 2020. In other words, the daily confirmed cases continued chronologically from March 17 while the preceding dates witnessed a zigzag or spatial incidence level for both countries. Thus, we benched our graphical comparison from the date of the concurrent dataset for the two countries. Data for the graphical analysis therefore covered from March 17 to April 26, 2020. Figure 1 represents the relative daily confirmed cases of COVID-19 for both Italy and Nigeria. This is simply the illustration of contribution of the two countries to the burden of COVID-19 in the global domain. Daily contribution from Nigeria is far below 100 cases while Italy is relatively above a thousand compared to the United States with a figure over 10000 as at April 26, 2020, while China that was previously high is currently below 100 (Figure 1). The graph depicts that the United States' incidence was far below China's and Italy's numbers at the onset but later outran other countries and now stands as the country with the highest incidence and fatality rates of coronavirus.

Figure 2 graphically shows the gap in the number of COVID-19 cases reported for Italy and Nigeria within the same period analyzed for the two countries and April 26, 2020. While, by comparison, the number reported for Nigeria is relatively low (hardly visible and parallel to the horizontal axis), it is positively sloping upward from left to right in respect of Italy. Figure 3 illustrates the percentage change in the incidence rate of COVID-19 for the two countries in consideration and the relative distinctions in the movement of the curves for both countries. Nigeria's curve on the percentage change in incidence curve is observed to be negatively downward sloping from left to right, suggesting a reduction in the rate. However, the curve demonstrated a zigzag sloping as shown in Figure 3, and the percentage change for Italy was relatively consistently low.
The last figure (Figure 4) was used to demonstrate the percentage change in COVID-19 fatality rates between Italy and Nigeria. There is no doubt that the curves exhibited decline but a zigzag curve movement was also observed for Nigeria's curve, while it demonstrated a relatively steady decline for Italy.

However, the comparison between the selected demographic characteristics of the two countries shows relative divergences in population density per square kilometers, proportion of doctors per 1000 patients, and number of hospital beds per 10000 population. While the physician/ patient ratio in Nigeria is 0.4 implying about one physician for 2500 patients, the ratio is 4.2 for Italy indicating one physician for 238 patients (Table 2). However, the ratio of number of hospital beds per 10000 population is 5.0 and 3.18 for Nigeria and Italy. respectively. The statistics is likened to 2,000 beds per 10000 population in Nigeria and 3,145 per 10000 population in Italy (Table 2). The population density that is calculated as the country area occupied divided by the total population shows variant results. While Nigeria population density per square $\mathrm{km}$ shows 221 human population per $\mathrm{km}^{2}$, it is 206 people per square kilometer for Italy (Table 2).

\section{Current Measures and Precautions}

Italy has placed all her population under self-quarantine. Other parts of the immediate measures taken by the Italian government have been immediate suspension of flights to and from China on 31 January 2019 with the closure originally meant for six months [54]. Italian government also introduced thermal scanners and temperature checks for all arriving passengers at the international Italian airports [54]. In addition, the government of Italy banned all movements except those on health emergencies and other special duties. In addition, more health facilities have been constructed between the time of the first case and now in both countries.

The specific trending measures are washing of hands, cleaning and disinfecting surfaces, and avoiding close contact with others. Considering the fact that part of the 


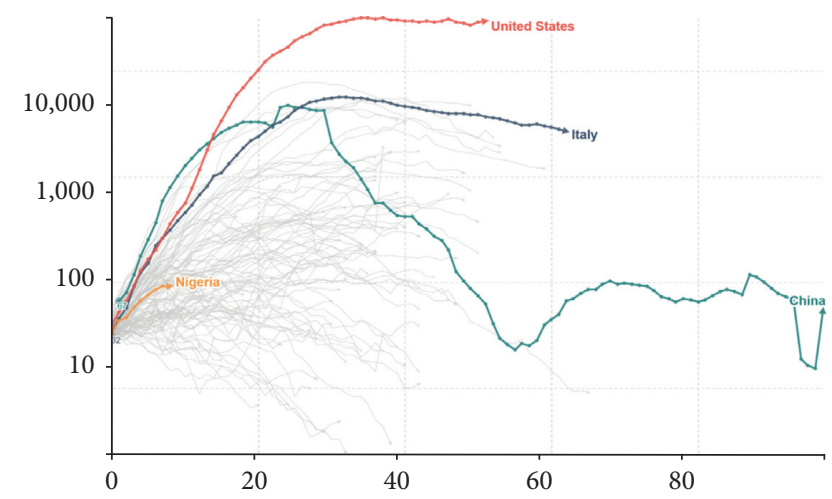

FIgURE 1: Daily confirmed COVID-19 cases (Nigeria, Italy, US, and China).

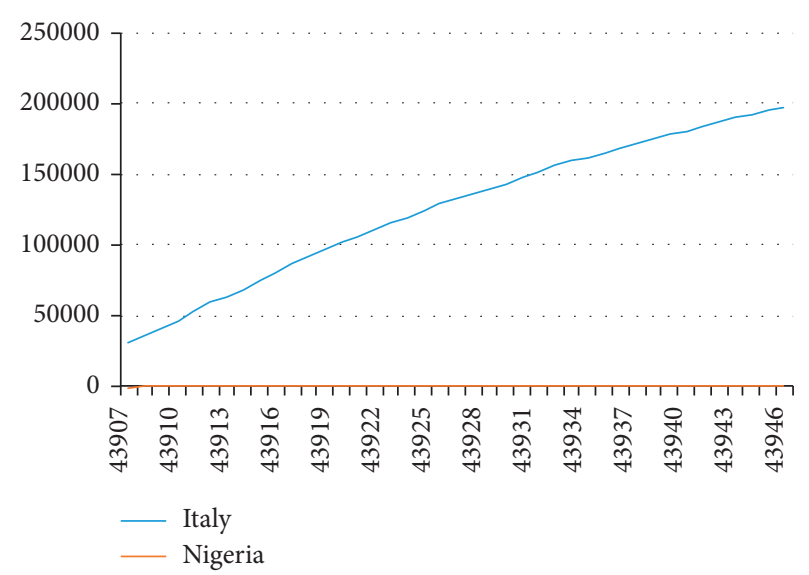

Figure 2: COVID-19 incidence in Italy and Nigeria (April 26, 2020).

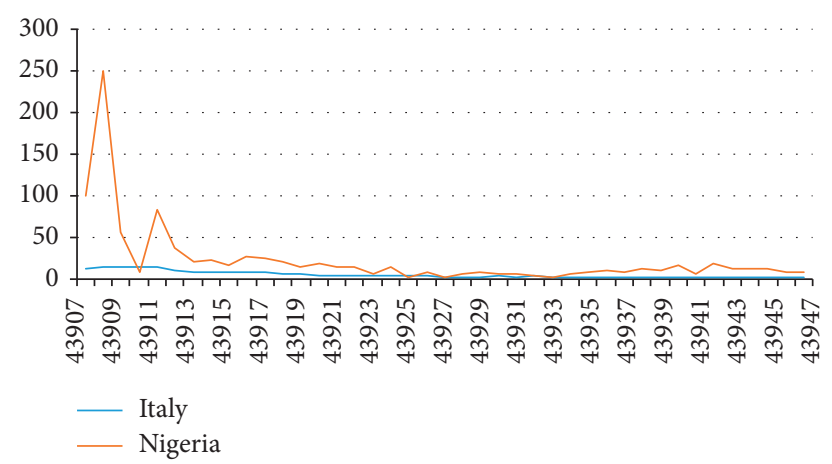

Figure 3: Percentage change in COVID-19 incident rates in Italy and Nigeria (April 26, 2020).

African culture is greeting and exchange of pleasantries, the World Health Organisation has recommended the people adopt greeting system that include nodding, waving of hands, a bow, and other gestures that are devoid of physical contact [28] (United Nations Children's Fund) [55, 56]. The public has also been advised to avoid touching eyes, nose, and mouth with their hands. Hands can pick up viruses especially when it is used in touching many surfaces. Thus,

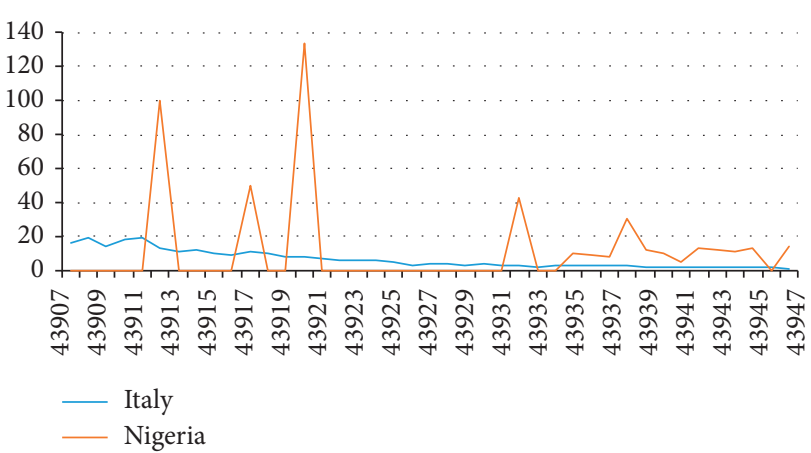

FIgURe 4: Percentage change in COVID-19 fatality rates in Italy and Nigeria (April 26, 2020).

TABLe 2: Selected demographics, health indicators, and COVID-19 incidences for Nigeria and Italy.

\begin{tabular}{lcc}
\hline & Italy & Nigeria \\
\hline Demographics & & \\
$\quad$ Population & $60,550,075$ & $200,963,599$ \\
Land area $\left(\mathrm{km}^{2}\right)$ & 294,140 & 910,768 \\
Population density (per km $\left.{ }^{2}\right)$ & 206 & 221 \\
$\quad$ Density (per mile ${ }^{2}$ ) & 533 & 572 \\
Selected health indicators & & \\
$\quad$ Number of state/province & 110 & 36 \\
Hospital beds/10000 population & 3.18 & 5.0 \\
No. of physicians/1000 persons & 4.2 & 0.4 \\
Population growth rate & 0.23 & 2.6 \\
COVID-19 & & \\
Incidences & 197,675 & 1,273 \\
Deaths & 26,644 & 40 \\
Recovery & 64,928 & 239 \\
\hline
\end{tabular}

Sources: computed for this study from reviewed reports.

the use of contaminated hands to rub the face, nose, mouth, or eyes can make the person vulnerable to the infection $[28,39,55]$, in addition to practising good respiratory hygiene by covering the mouth and nose with disposable tissue or a handkerchief and washing such handkerchief or coughing and sneezing at bent elbows [28] (United Nations Children's Fund) [39, 55].

\section{Discussion}

The study relatively chronicled the postmillennial era challenges faced by Nigeria from insurgency, to Ebola, kidnapping, serial killings, and herdsmen/farmers clashes and now the Corona pandemic in the face of the challenge of meeting the goals of sustainable development. It also highlighted the various environmental challenges encumbering Italy. From the materials reviewed, it can be seen that coronavirus has no boundary and everyone could be vulnerable. Economically, it stampeded most sectors and was a shock in transportation and logistic businesses. Open markets (as commonly found in sub-Saharan Africa) and stores were locked down, and streets were deserted. Schools and colleges (both public and private) were closed. While salaries and allowances from the public enterprises could be 
guaranteed, the same cannot be held for the private business sector whose employee's take-home pay is a function of the generated income [57, 58]. Nevertheless, COVID-19 has created unity among nations; the lockdown, sit-at-home order has created and reinstated bounds within family and communities. Efforts to curb the spread defiled unicountry approach and created a multilateral unification among all stakeholders and the populace. Notwithstanding, our report could spur or serve as basis for future investigation on the postpandemic health status of the citizenry in both Nigeria and Italy.

The many problems of Nigeria and Italy could be responsible for their lack of preparedness towards the outbreak of disease. The preoccupation with quenching insurgency, communal clashes, and environmental problems could befog the reasoning for guiding against the utmost health consequences of these challenges. Health is population and population is health. Deficiency in health facilities exposes the country more to health disasters and often results in insufficient capacity to care for population where the need arises. The revelation of the low physician/patient ratio of 1 : 2500 in Nigeria and 1:328 in Italy signals danger for Nigeria, should the epidemic extend beyond the current level. If Italy with its high physician/patient ratio and lower population density compared to Nigeria could suffer as much fatality as experienced with ongoing incidences of COVID-19, then other countries with abysmally low level as seen for Nigeria should prepare to face harder time in disaster period.

Notwithstanding the above, as at the time of writing this report, the fatality rate in Nigeria has not increased sharply despite the low level of health facilities compared to Italy or other affected developed nations. Government response or perhaps inadequate testing facility could have accounted for this. As at the $31^{\text {st }}$ day of COVID-19 infection in Nigeria, the percentage incidence increase was $20 \%$ while Italy figure remained relatively $\leq 2$ persons. However, around this period, when the disease has been present for relatively 10 weeks (precisely 68 days) in Italy and 60 days in Nigeria, the percentage incidence increase was 5.3\% for Italy and 7.7\% for Nigeria. While the change in fatality was $7.5 \%$ increment in Italy, it was $14.3 \%$ in Nigeria. Notwithstanding, the people's experience, the government, and the local public health officials' handling of the immediate past-Ebola outbreaks and ongoing monitoring of Lassa fever could have also played out $[2,13,59]$.

Although the levels of proactiveness (or reactiveness) by the different governments were not measured in this study, the measures that were rolled out suggest urgent attention was devoted to the epidemic by the governments of the two countries. However, the total lockdown might not be absolutely benign. The challenge in food rationalization or purchase, the ensuing overcrowding including its immediate and long-run health effects, especially in Nigeria, where average family is large and all members could present at home, and the restrictive mass quarantine could create more anxiety at home and escalate incidence rate. In addition, the current situation could expose the inefficiency of the health system and the laxity and level of depravedness in the health systems of the two countries. The massive construction of new hospitals, intensive care units, and isolation centers are pointers to past omissions on citizens health at the level of government and such error should not be repeated in the future.

The observation that the incidence percentage change has not exceeded 20\% (Nigeria) and 5.0\% (Italy) in April seems to portend better possibility that the health systems is coping adequately with the disease. Also, Nigerian cases that were low at the onset could be (perhaps) due to the quick intervention by the government and alertness of the health system. However, since there is no immediate curative vaccine or definite cure for the disease currently, maintenance of the existing measures could be sustained.

Italy is a developed economy with high standard of living, higher employment rate, and good financial structure including excellent telecommunications. High proportion of people with infectious disease drains the reputation of any country and, if persistent, it could relegate such country to lower economy class. This could be a bad omen for the future stabilization of development of Italy if she continues to suffer from natural and environmental disasters including COVID-19. Similar fate awaits Nigeria if she should continue to experience human-made and natural turbulence like the current pandemic situation. Finally, recession could be inevitable if the pandemic and the lockdown should continue in these two countries.

\section{Conclusion and Recommendations}

The study outlined some similarities and divergences between Nigeria and Italy. It identified that both countries had similar antecedence of natural and human-made disasters and are currently experiencing COVID-19 pandemic but in different dimensions especially in terms of magnitude. The coronavirus entered the two countries following a similar pattern. However, demographically, Italy and Nigeria are two countries apart: while Nigeria is rich in younger population ( $\leq 15$ years), relatively, the average age in Italy is 45.2 years. The study also identified the total lockdown as a major initiative of both Italian and Nigerian governments, though Nigeria lockdown came weeks after Italy has started. Recommended measures are generally tilted towards personal hand hygienic practices. However, since lockdown is already taking place in both countries and other nations, the authors suggest that economic digitalisation such as online businesses, e-learning, and e-governance that guarantee minimal human physical contact should be encouraged in Nigeria, Italy, and the rest of the world for plausible prevention and management of COVID-19 pandemic. In addition, closer monitoring and control of the pandemic spread in still unavoidable in Nigeria considering the current nonsteady decline in the fatality level.

\section{Data Availability}

The principal data used for this study are extracted from different sources as indicated below, and the computation used to support the findings of this study are included within 
the article. (1) Protezione Civile (2020), Protezione Civile Bulletin at 18:00 CET, The Dipartimento della Protezione Civile, Italy (http://www.protezionecivile.gov.it/web/guest/ media-comunicazione/comunicati-stampa) (https://en. wikipedia.org/wiki/2020_coronavirus_pandemic_in_Italy). (2) Nigeria Centre for Disease Control (NCDC), March 31, 2020 (https://www.ncdc.gov.ng/diseases/sitreps/?cat= 14\&name $=$ An\%20update $\% 20$ of\%20COVID-19\%20outbreak\% 20in\%20Nigeria) . (3) Population Reference Bureau (PRB), The 2019 World Population Data Sheet, Population Reference Bureau (PRB), Washington DC (https://www.prb.org/ worldpopdata).

\section{Conflicts of Interest}

The authors declare that they have no conflicts of interest.

\section{Acknowledgments}

The authors acknowledge the support of the Covenant University Centre for Research, Innovation and Discovery CUCRID) for the guidance and The Scientific World Journal for waiving the article processing charge (APC) on the publication of this paper. They also dedicate this work to all lives lost due to coronavirus pandemic.

\section{References}

[1] C. L. Althaus, N. Low, E. O. Musa, F. Shuaib, and S. Gsteiger, "Ebola virus disease outbreak in Nigeria: transmission dynamics and rapid control," Epidemics, vol. 11, pp. 80-84, 2015.

[2] Nigeria Centre for Disease Control (NCDC), Disease Information-Ebola, Nigeria Centre for Disease Control (NCDC), Abuja, Nigeria, 2017, https://ncdc.gov.ng/diseases/ info/E.

[3] N. Abad, T. Malik, A. Ariyarajah et al., "Development of risk reduction behavioral counseling for Ebola virus disease survivors enrolled in the Sierra Leone Ebola virus persistence study, 2015-2016," PLoS Neglected Tropical Diseases, vol. 11, no. 9, Article ID e0005827, 2017.

[4] World Health Organisation, World Health Organization Situation Report Ebola Virus Disease, World Health Organisation, Geneva, Switzerland, 2016, http://apps.who.int/iris/ bitstream/handle/10665/208883/ebolasitrep_10Jun2016_eng. pdf;sequence $=1$.

[5] S. Baize, D. Pannetier, L. Oestereich et al., "Emergence of Zaire Ebola virus disease in Guinea," New England Journal of Medicine, vol. 371, no. 15, pp. 1418-1425, 2014.

[6] L. Baseler, D. S. Chertow, K. M. Johnson, H. Feldmann, and D. M. Morens, "The pathogenesis of Ebola virus disease," Annual Review of Pathology: Mechanisms of Disease, vol. 12, no. 1, pp. 387-418, 2017.

[7] Centers for Disease Control and Prevention (CDC), 20142016 Ebola Outbreak Distribution in West Africa, Centers for Disease Control and Prevention (CDC), Atlanta, GE, USA, 2017, https://www.cdc.gov/vhf/ebola/history/2014-2016outbreak/distribution-map.html.

[8] M. Winters, M. F. Jalloh, P. Sengeh et al., "Risk communication and Ebola-specific knowledge and behavior during 2014-2015 outbreak, Sierra Leone," Emerging Infectious Diseases, vol. 24, no. 2, pp. 336-344, 2018.
[9] N. Alimba, "Probing the dynamic of communal conflict in Northern Nigeria," African Research Review, vol. 8, no. 1, pp. 177-204, 2014.

[10] E. O. Amoo, "Introduction to special edition on covenant university's perspectives on Nigeria demography and achievement of SDGs-2030," African Population Studies, vol. 32, no. 1, 2018.

[11] C. Anaele, "Herdsmen terror in Nigeria: the identity question and classification dilemma," American Research Journal of Humanities \& Social Science (ARJHSS), vol. 3, no. 3, pp. 10-25, 2020.

[12] F. C. Onuoha, "The Nigerian project and the quest for sustainable national security," in Internal Security Management in Nigeria, pp. 549-570, Springer, Berlin, Germany, 2019.

[13] O. Ipadeola, Y. Furuse, E. A. Ilori et al., "Epidemiology and case-control study of Lassa fever outbreak in Nigeria from 2018 to 2019," Journal of Infection, vol. 80, no. 5, pp. 578-606, 2020.

[14] G. S. Mesch and K. P. Schwirian, "Vaccination hesitancy: fear, trust, and exposure expectancy of an Ebola outbreak," Heliyon, vol. 5, no. 7, Article ID e02016, 2019.

[15] S.-Y. Ren, R.-D. Gao, and Y.-L. Chen, "Fear can be more harmful than the severe acute respiratory syndrome coronavirus 2 in controlling the corona virus disease 2019 epidemic," World Journal of Clinical Cases, vol. 8, no. 4, pp. 652-657, 2020.

[16] C. Sohrabi, Z. Alsafi, N. O’Neill et al., "World Health Organization declares global emergency: a review of the 2019 novel coronavirus (COVID-19)," International Journal of Surgery, vol. 76, pp. 71-76, 2020.

[17] D. Alessio, G. Marin, and R. Andrea, "Environmental disasters and electoral cycle: an empirical analysis on floods and landslides in Italy," Environmental and Resource Economics, vol. 74, no. 2, pp. 625-651, 2019.

[18] A. Cerase, M. Crescimbene, F. La Longa, and A. Amato, "Tsunami risk perception in southern Italy: first evidence from a sample survey," Natural Hazards and Earth System Sciences, vol. 19, no. 12, pp. 2887-2904, 2019.

[19] V. Saini, Coronavirus: Lessons from Italy. The Analysis, Euobserver, Brussels, Belgium, 2020, https://euobserver.com/ coronavirus/147753.

[20] F. Guzzetti, C. P. Stark, and P. Salvati, "Evaluation of flood and landslide risk to the population of Italy," Environmental Management, vol. 36, no. 1, pp. 15-36, 2005.

[21] P. Salvati, O. Petrucci, M. Rossi, C. Bianchi, A. A. Pasqua, and F. Guzzetti, "Gender, age and circumstances analysis of flood and landslide fatalities in Italy," Science of the Total Environment, vol. 610-611, pp. 867-879, 2018.

[22] Carol, Population Growth and the Spread of Diseases, Population Education, Washington, DC, USA, 2014, https:// populationeducation.org/population-growth-and-spreaddiseases/.

[23] M. Iaccarino, "Water, population growth and contagious diseases," Water, vol. 11, no. 2, p. 386, 2019.

[24] S. C. Ng, G. G. Kaplan, W. Tang et al., "Population density and risk of inflammatory bowel disease," The American Journal of Gastroenterology, vol. 114, no. 1, pp. 107-115, 2019.

[25] P. M. Tarwater and C. F. Martin, "Effects of population density on the spread of disease," Complexity, vol. 6, no. 6, pp. 29-36, 2001.

[26] M. Goodwin and J. Seladi-Schulman, COVID-19 vs. SARS: How Do They Differ?, Healthline, San Francisco, CA, USA, 2020, https://www.healthline.com/health/coronavirus-vssars.

[27] K. Ramphul and S. G. Mejias, "Coronavirus disease: a review of a new threat to public health," Cureus, vol. 12, no. 3, pp. 1-7, 2020. 
[28] A. Amante and C. Balmer, "Coronavirus Outbreak Grows in Northern Italy," in 16 Cases Reported in One Day, G. Jones, Ed., Reuters, London, UK, 2020, https://www.reuters.com/article/ us-china-health-italy-outbreak/coronavirus-outbreak-grows-innorthern-italy-16-cases-reported-in-one-day-idUSKBN20F2GF.

[29] Nigeria Centre for Disease Control (NCDC), First Case of Corona Virus Disease Confirmed in Nigeria, Nigeria Centre for Disease Control, Abuja, Nigeria, 2020, https://ncdc.gov.ng/news/ 227/first-case-of-corona-virus-disease-confirmed-in-nigeria.

[30] O. Abodunrin, G. Oloye, and B. Adesola, "Coronavirus pandemic and its implication on global economy," International Journal of Arts, Languages and Business Studies, vol. 4, pp. 13-23, 2020.

[31] S. P. Adhikari, S. Meng, Y.-J. Wu et al., "Epidemiology, causes, clinical manifestation and diagnosis, prevention and control of coronavirus disease (COVID-19) during the early outbreak period: a scoping review," Infectious Diseases of Poverty, vol. 9, no. 1, pp. 1-12, 2020.

[32] W. Guan, Z. Ni, Y. Hu et al., "Clinical characteristics of coronavirus disease 2019 in China," New England Journal of Medicine, vol. 382, no. 18, pp. 1708-1720, 2020.

[33] E. Mahase, "China coronavirus: what do we know so far?" British Medical Journal, vol. 368, p. m308, 2020.

[34] N. Adams, "Cracking the code to the 2019 novel coronavirus (COVID-19): lessons from the eye," Eye Reports, vol. 6, no. 1, pp. 1-6, 2020.

[35] D. Cucinotta and M. Vanelli, "WHO declares COVID-19 a pandemic," Acta Bio-Medica: Atenei Parmensis, vol. 91, no. 1, pp. 157-160, 2020.

[36] J. A. Backer, D. Klinkenberg, and J. Wallinga, "Incubation period of 2019 novel coronavirus (2019-nCoV) infections among travellers from Wuhan, China, 20-28 January 2020," Eurosurveillance, vol. 25, no. 5, 2020.

[37] D. Baud, X. Qi, K. Nielsen-Saines, D. Musso, L. Pomar, and G. Favre, "Real estimates of mortality following COVID-19 infection," The Lancet Infectious Diseases, 2020.

[38] WHO-China Joint Mission, Report of the WHO-China Joint Mission on Coronavirus Disease 2019 (COVID-19), vol. 40, WHO-China Joint Mission on Coronavirus Disease, Geneva, Switzerland, 2020, https://www.who.int/docs/default-source/ coronaviruse/who-china-joint-mission-on-covid-19-finalreport.pdf.

[39] World Health Organization, Coronavirus Disease 2019 (COVID-19): Situation Report, vol. 51, World Health Organization, Geneva, Switzerland, 2020https://apps.who.int/iris/ bitstream/handle/10665/331475/nCoVsitrep11Mar2020-eng. pdf.9.

[40] J. A. Backer, D. Klinkenberg, and J. Wallinga, "The incubation period of 2019-nCoV infections among travellers from Wuhan," Eurosurveillance, vol. 25, no. 5, 2020.

[41] R. De Angelis, Italian Foreign Policy in West Africa: Between Governmental and Business Action to Fulfil Opportunities and Needs in the Region, LUISS, Rome, Italy, 2019.

[42] M. Giovanetti, D. Benvenuto, S. Angeletti, and M. Ciccozzi, "The first two cases of 2019-nCoV in Italy: where they come from?" Journal of Medical Virology, vol. 92, no. 5, pp. 518-521, 2020.

[43] D. M. Salute, "Covid-19-Situazione in italia," Roma, I: Governo-Repubblica Italiana, vol. 3, no. 11, 2020.

[44] Central Intelligence Agency (CIA), The World Fact Book. Age Structure, Central Intelligence Agency, McLean, VI, USA, 2020, https://www.cia.gov/library/publications/the-worldfactbook/fields/341.html.
[45] G. Calcagnini and F. Perugini, "A well-being indicator for the Italian provinces," Social Indicators Research, vol. 142, no. 1, pp. 149-177, 2019.

[46] Eurostat, NUTS-nomenclature of Territorial Units for Statistics, Eurostat, Brussels, Belgium, 2018, https://ec.europa.eu/ eurostat/web/nuts/national-structures-eu.

[47] Population Reference Bureau (PRB), The 2019 World Population Data Sheet, Population Reference Bureau (PRB), Washington, DC, USA, 2019, https://www.prb.org/worldpopdata.

[48] NationMaster, Geography Land Area Sq. km: Countries Compare, NationMaster, Woolwich, Australia, 2019, https:// www.nationmaster.com/country-info/stats/Geography/Landarea/Sq.-km.

[49] World Bank Group, Physicians Per 1000 Persons, World Bank Group, Washington, DC, USA, 2019, https://data.worldbank. org/indicator/SH.MED.PHYS.ZS.

[50] R. De Vogli, R. Mistry, R. Gnesotto, and G. A. Cornia, "Has the relation between income inequality and life expectancy disappeared? Evidence from Italy and top industrialised countries," Journal of Epidemiology \& Community Health, vol. 59, no. 2, pp. 158-162, 2005.

[51] L. Chamberlain, Life Expectancy for Countries, Infoplease, Boston, MA, USA, 2020, https://www.infoplease.com/world/ health-and-social-statistics/life-expectancy-countries.

[52] O. Odiboh, O. Omojola, and K. Oyesomi, "Awareness and sources of knowledge on men's penile health in Lagos, Nigeria," Cogent Social Sciences, vol. 6, no. 1, Article ID 1713710, 2020.

[53] European Centre for Disease Prevention and Control (ECDC), Situation Update Worldwide, as of 31 March 2020-Epidemiological Update, European Centre for Disease Prevention and Control, Solna Municipality, Sweden, 2020, https://www.ecdc.europa.eu/en/geographical-distribution-2019ncov-cases.

[54] S. Manandhar, P. Nakarmi, and N. Baniya, "A novel coronavirus emerging in world-key questions for developing countries and under developed countries," North American Academic Research, vol. 3, no. 02, pp. 473-497, 2020.

[55] United Nations Children's Fund (UNICEF), FACT SHEET: Handwashing with Soap, Critical in the Fight against Coronavirus, Is "Out of Reach" for Billions, United Nations Children's Fund, New York, NY, USA, 2020, https://www. unicef.org/press-releases/fact-sheet-handwashing-soap-criticalfight-against-coronavirus-out-reach-billions.

[56] World Health Organisation, Coronavirus Disease (COVID-19) Advice for the Public. Basic Protective Measures against the New Coronavirus, World Health Organisation, Geneva, Switzerland, 2020, https://www.who.int/emergencies/ diseases/novel-coronavirus-2019/advice-for-public.

[57] M. W. L. Elsby and G. Solon, "How prevalent is downward rigidity in nominal wages? International evidence from payroll records and pay slips," Journal of Economic Perspectives, vol. 33, no. 3, pp. 185-201, 2019.

[58] S. Lovett, T. Coyle, G. Banerjee, and S. Hardebeck, "Measuring managerial effectiveness in handling pay cuts," Journal of Applied Management and Entrepreneurship, vol. 13, no. 4, p. 23, 2008.

[59] Nigeria Centre for Disease Control (NCDC), An Update of COVID-19 Outbreak in Nigeria, Nigeria Centre for Disease Control, Abuja, Nigeria, 2020, https://www.ncdc.gov. $\mathrm{ng} /$ diseases/sitreps/?cat=14\&name=AnupdateofCOVID19 outbreakinNigeria. 